\title{
First Report on the Occurrence of Invasive Macrophyte Elodea canadensis Michx. in Sapanca Lake
}

\author{
Sezgi Ersoy' ${ }^{1}$, Yelda Aktan Turan ${ }^{1}$ \\ IIstanbul University, Faculty of Aquatic Sciences, Department of Marine and Inland Water Resources Management, Istanbul, Turkey
}

ORCID IDs of the authors: S.E. 0000-0002-1081-5719; Y.A.T. 0000-0001-7920-8979

Please cite this article as: Ersoy S, Aktan Turan Y. First Report on the Occurrence of Invasive Macrophyte Elodea canadensis Michx. in Sapanca Lake. Eur J Biol 2019; 78(2): 103-107. DOI: 10.26650/EurJBiol.2019.0018

\begin{abstract}
Objective: Elodea canadensis Michx. is a common invasive aquatic macrophyte that has successfully spread along European, Asian and Australian inland waters. The aim of this study is to evaluate the presence and distribution of an alien and invasive species, E. canadensis, in Sapanca Lake (Turkey) for the first time.

Materials and Methods: Sampling for macrophytes and main environmental parameters was carried out seasonally between the years 2016 and 2017 along the coasts of Sapanca Lake. Macrophytes samples were taken from bounded areas. Morphological observations were made on both unfixed-living and dried materials, and morphological details were observed under a light microscope.

Results: Elodea canadensis Michx. was reported for the first time in Sapanca Lake during the spring period of 2016 with water temperatures of $20.9 \pm 0.9^{\circ} \mathrm{C}$. A total of six submerged macrophytes species were recorded together with $E$. canadensis.

Conclusion: The first record of this species in Sapanca Lake is important for contributing to the changing biodiversity dynamics of the lake and also contributes to the assessment of the possible ecological and economic risks of the region in terms of lake management.
\end{abstract}

Keywords: Invasive macrophytes, Elodea canadensis, Sapanca Lake

\section{INTRODUCTION}

Aquatic macrophytes play an important role in both structuring and functioning communities in aquatic environments (1). They contribute significantly to the productivity and biodiversity in the littoral region by representing a suitable habitat for micro and macro flora and fauna as well as a significant number of ecological and economical species. Moreover, they have an important role in ensuring nutrient dynamics, protecting against coastal erosion and in stabilising the sediments by reducing the negative effect of the wave (2). Moreover, recent studies have indicated that the invasion of alien aquatic macrophytes introduced by natural or anthropogenic means has been a highlighted issue. Hussner (3) reported findings of 96 alien aquatic plant species from European inland waters, and Elodea canadensis Michx. was reported to be the most widely distributed alien aquatic plant in Europe.

E. candensisis is a submerged aquatic plant belonging to Hydrocharitales (Magnoliophyta) (4). The native distribution of this species is reported to be from North American and Canadian Inland waters (4-6) but it is a common invasive species in Europe, Asia and Australia $(4,6)$. The first record of the plant in European waters came from Ireland in 1836 (6) and later studies indicated that it successfully spread and rapidly colonised in north and central European shallow lakes and streams $(3,7-12)$ and then extended to Asian fresh waters (13). E. canadensis has been defined as a "catastrophic phenomenon" in Baikal Lake (14) due to forming fast and uncontrolled thriving populations in a very short space of time. The species has been categorized as 
a least concern (LC) species by the International Union for Conservation of Nature (IUCN) (15). Recent studies indicate that E. canadensis is now widespread globally with the exception of Iceland, Greenland, the Faroe Islands and the Norwegian islands (16) and is reported to be a noxious weed in freshwaters (4).

In Turkey, E. canadensis was first reported in the Thrace Region (North-western part of Turkey) by Davis (17). Later, the presence of the species was noted in Gala Lake (18) and also in some drainage channels in the surrounding areas (19). In 2005, the first record of the species was given from western Anatolia (Eğirdir Lake, South-western part of Turkey) and in the following years its spreading to the entire lake area was reported (20). The presence of this invasive species poses an ecological, sociological and economic threat in freshwater ecosystems (21, 22). Elodea has high invasion success, considering the advantage such as the high tolerance to changing environmental factors, fast vegetative reproduction ability by fragments and easy dispersion vectors (irrigation canal, animals, fishing activities and recreational use of waters). Increasing nutrient input and eutrophication process also promote its mass development and spread. Considering its widespread appearance and rapid colonization success in European waters, research scientists need to know its spreading areas and to make an evaluation of its effects on the biodiversity of the lake ecological status. This study reports the presence of an alien and invasive species, $E$. canadensis, in Sapanca Lake for the first time.

Sapanca Lake, located in the north-western part of Turkey $\left(40^{\circ} 43^{\prime} \mathrm{N}\right.$ and $\left.30^{\circ} 15^{\prime} \mathrm{E}\right)$ is a tectonic lake, with a surface area of $47 \mathrm{~km}^{2}$ and maximum depth of $55 \mathrm{~m}$. At a local level, the lake is an important freshwater source of drinking water and is used for domestic water and industrial needs, besides commercial and sport fisheries. The catchment area consists of small towns, villages and forests and the lake is used for tourism and various recreational activities. This lake is fed by several creeks and partly by groundwater. The shallow shores are covered by a wide vegetation belt. Sapanca Lake with its winter overturn is a typical warm-monomictic lake. The lake water is mixed thoroughly from top to bottom in February-March, providing enrichment of the surface layer with nutrients from deep waters as well as ventilation of bottom waters (23). Though there is no direct discharge of waste into the lake, chemical pollutants of both domestic and agricultural origin find their way into the lake through surface-runoff (24). Before 1980, a few studies of its principal limnological properties showed the lake to contain low concentrations of dissolved inorganic ions and the water to be adequate for drinking, industrial usage and irrigation. Recently there has been some impact of pollutants, particularly sewage effluent. Towards the end of the 1990s some colour changes indicating water-blooms were occasionally observed and routine studies revealed that a cyanobacterium, Planktotrix rubescens (De Candolle ex Gomont) Anagnostidis\&Komarek was responsible $(23,25)$. In recent years, cyanobacterial blooms frequently occur as a result of degradation of water quality and the eutrophication in the lake.

\section{MATERIALS AND METHODS}

Field observation and sampling for macrophytes and main environmental parameters was carried out seasonally between the years 2016 and 2017 along the coasts of Sapanca Lake (Figure 1). Moreover, short time-scale samplings (weekly) along the coast of the Lake were conducted from July to August in summer periods. Aquatic plants were observed along the coast by means of a viewing tube and collected using a rake. Macrophytes samples were taken from bounded areas with three replicates and their relative abundance was estimated based on their dry-wet weight in each sampling area. Morphological observations were made on both unfixed-living and dried materials and morphological details were observed under a light microscope in the laboratory.

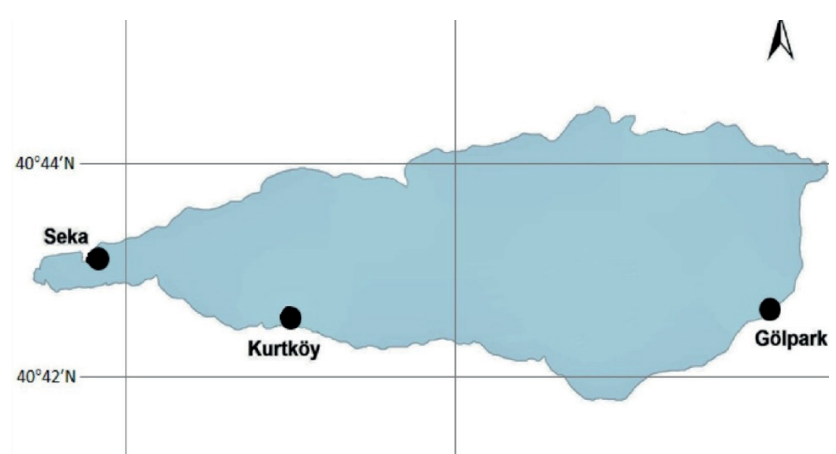

Figure 1. Map of Sapanca Lake showing sites where Elodea canadensis Michx. was found

The identification of Elodea was made according to Casper and Krausch (5), Bowmer et al. (4) and Simpson (26). Moreover, main environmental parameters influencing the presence/ absence of the species were recorded. Water temperature, dissolved oxygen, conductivity and $\mathrm{pH}$ were measured in situ with a multiparameter prob and transparency with a Secchi disc. Water samples for nutrients and chlorophyll $a$ were taken from surface. For chlorophyll $a$ analysis, water was filtered through a glass fiber filter (Whatman GF/C) and Chlorophyll $a$ concentration was determined spectrophotometrically (27). Nutrients (reactive phosphorus, nitrate and nitrite nitrogen, and silicate) were analysed in the laboratory according to standard analytical techniques (28). Measured environmental parameters and chlorophyll $a$ results of Lake Sapanca surface water were given by the mean with standard deviations.

\section{RESULTS}

The first observation of $E$. canadensis Michx. was recorded in the spring of 2016 at water temperatures of $20.9 \pm 0.9^{\circ} \mathrm{C}$ during the preliminary study for a project on aquatic macrophytes of Sapanca Lake. In the routine sampling which was on-going during 2017, the species was observed again from a depth of 1-3 meters at the Seka and Kurtköy regions of the Lake during the summer. When the presence of the species was monitored 
Table1: Measured environmental parameters and chlorophyll a means with standard deviations (SD) of Lake Sapanca surface water

\begin{tabular}{lcc}
\hline Parameters & Range & Mean \pm SD \\
\hline Water temperature $\left({ }^{\circ} \mathrm{C}\right)$ & $5.8-28.0$ & $17.6 \pm 0.4$ \\
\hline $\mathrm{pH}$ & $6.9-8.2$ & $7.5 \pm 0.1$ \\
\hline Dissolved oxygen $\left(\mathrm{mg} \mathrm{l}^{-1}\right)$ & $6.6-10.4$ & $8.6 \pm 0.4$ \\
\hline Conductivity $\mathrm{s} \mathrm{cm}^{-1}$ & $248-286$ & $265 \pm 5$ \\
\hline Water transparency $(\mathrm{m})$ & max & max \\
\hline$\left(\mathrm{NO} 2+\mathrm{NO}_{3}\right)-\mathrm{N}\left(\mathrm{mg} \mathrm{l}^{-1}\right)$ & $2.16-12.10$ & $4.54 \pm 0.17$ \\
\hline $\mathrm{PO}_{4}-\mathrm{P}\left(\mathrm{mg} \mathrm{l}^{-1}\right)$ & $2.25-3.35$ & $2.34 \pm 0.10$ \\
\hline Chlorophyll a $\left(\mathrm{mg} \mathrm{l}^{-1}\right)$ & $1.62-22.73$ & $8.9 \pm 3.4$ \\
\hline
\end{tabular}

seasonally, it was observed that its spreading area extended to the inner western shore of the lake during the summer period (from June to August) at temperatures of $27.4 \pm 0.5^{\circ} \mathrm{C}$. Measured environmental parameters and chlorophyll $a$ means with standard deviations of Lake Sapanca surface water are given in Table 1. The species had the highest biomass during the autumn period ( $209 \mathrm{~g} / \mathrm{m}^{2}$ in dry weight) with temperatures of $15.8 \pm 0.3^{\circ} \mathrm{C}$, and in addition to these areas it was also recorded at Gölpark region along the eastern shore of the lake. During the study period, a total of six submerged macrophytes species (Myriophyllum spicatum L., Ceratophyllum demersum L., Najas minor All., Chara sp., Potamogeton perfoliatus L. and Potamogeton lucens L.) were reported together with $E$. canadensis.

Elodea is a perennial aquatic submerged plant measuring 20$30 \mathrm{~cm}$ in length. The identification of $E$. canadensis is based
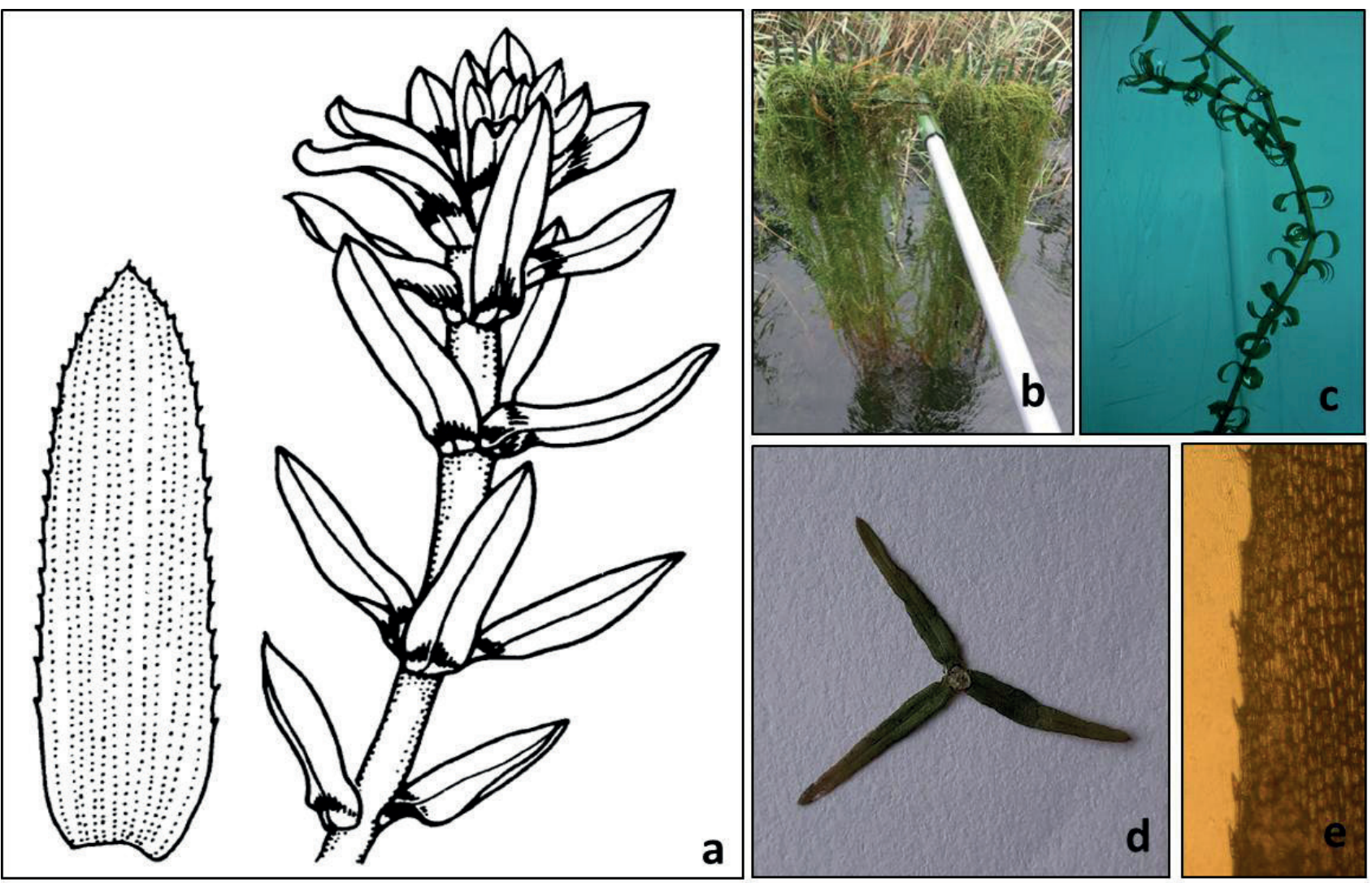

Figure 2. Elodea canadensis Michx., (a) morphological illustration of leaves, from Bowner et al (4) (Illustration by Christine Payne, from Sainty and Jacobs, 1988), (b-c) during the sampling from Sapanca Lake by rake, and (d-e) detailed photos of leaves. 
on leaf characteristics. Towards the stem apex leaves usually overlap in regular rows and lie along the stem (4). In collected samples from Sapanca Lake, E. canadensis is identified with its three oblong linear leaves in whorls, the size of leaves being $8.96 \pm 1.89 \mathrm{~mm}$ in length and $1.86 \pm 0.38 \mathrm{~mm}$ in width at the midpoint (Figure 2).

\section{DISCUSSION}

Macrophytes are key elements of the lake ecosystem, contributing significantly to the productivity of littoral areas. However, during the last decades, the degradation of natural balance as a result of increased human activities has led to the destruction of habitats, loss of biodiversity and/or excessive increase in some species with a decrease in water quality. Several studies have focussed on alien species and the impact of invasive macrophytes on aquatic systems, and these studies have revealed that this problem is one of the major environmental problems in inland water $(3,29,30)$.

In this study, Elodea canadensis Michx., is recorded for the first time in Sapanca Lake. Elodea is a flowering plant but vegetative reproduction by fragments is also very common (9). Earlier studies showed that the species has high ecological tolerance with temperatures of $10-25^{\circ} \mathrm{C}$ and $\mathrm{pH} 6.5-10$, and it can be rapidly dominant in waters with average nutrient content, especially ranging from mesotrophic to eutrophic waters $(8,31)$. These ecological and biological characteristics of Elodea contribute to its success at being invasive. In the present study, the total biomass of Elodea recorded during the summer and autumn periods ranged between 95 and $209 \mathrm{~g} /$ $\mathrm{m}^{2}$ in dry weight. Its distribution was limited to the southern part of the lake, and its relative abundance did not exceed $3 \%$ in the total macrophytes biomass. However, considering its widespread appearance in European waters $(3,12)$ as a result of global change caused by humans (29), and considering the colonization success of this species, the importance of monitoring studies on alien species is clear.

Alien species may have been introduced by natural or anthropogenic means. The origin of the population on the lake remains uncertain. The number of alien aquatic macrophytes in inland waters is much lower compared to the marine and terrestrial ecosystems due to geographical and climatic limitation and less introduction vector. More than 400 aquarium plants are used commercially and they considered as potential invaders to European inland waters (3). The commercial use of these species has also played an important role in the introduction of $E$. canadensis $(3,32)$. The presence and uncontrolled spread of these plants could cause important ecological and socio-economic losses in the future. Intervention against alien and invasive species is considerably difficult and costly. In addition, these interventions, which are mechanical, chemical and biological, have many disadvantages. The latest studies show that aquatic biosecurity is an important issue (30, 32-34). Biosecurity management in environmental and fishery policies, and raising awareness of the local people who use the lake for fishing, tourism and sporting activities play an important role in preventing the entrance and spread of alien species.

\section{CONCLUSION}

This study presents the appearance of Elodea canadensis Michx., an alien and invasive species, in Lake Sapanca and contributes to a new data on its distribution in inland water of Turkey. The first record of this species in Sapanca Lake is important as a contribution to the changing biodiversity dynamics of the lake and also contributes to assessing the possible ecological and economic risks of the region in terms of lake management.

Peer-review: Externally peer-reviewed.

Author Contributions: Conception/Design of study: Y.A.; Data Acquisition: S.E.; Data Analysis/Interpretation: Y.A., S.E.; Drafting Manuscript: Y.A., S.E.; Critical Revision of Manuscript: Y.A.; Final Approval and Accountability: Y.A, S.E.

Conflict of Interest: The authors declare that they have no conflicts of interest.

Financial Disclosure: This study was financially supported by the Research Fund of Istanbul University \{Project number: FLY2016-20468).

Acknowledgements: The authors thank Captain Harun UMUTLU and Mr. Mustafa ÖZDEMiR for his support during fieldwork and ali members of the Sapanca Inland Fish Culture Research and Application Unit.

\section{REFERENCES}

1. Søndergaard $M$, Johansson $S L$, Lauridsen $T L$, Jorgensen $T B$, Liboriussen $L$, Jeppesen E. Submerged macrophytes as indicators of the ecological quality of lakes. Freshwater Biol 2010; 55: 893908.

2. Barko JW, James WF. Effects of submerged aquatic macrophytes on nutrient dynamics, sedimentation, and resuspension. Jeppesen, $E$. Søndergaard, M., Søndergaard, M., Christoffersen K. editors, The Structuring role of submerged macrophytes in lakes. Ecological Studies (Analysis and Synthesis), 131. Springer, New York; 1998, 423pp.

3. Hussner A. Alien aquatic plant species in European countries. Weed Res 2012; 52: 297-306.

4. Bowmer HK, Jacobs SWL, Sainty GR. Identification, biology and management of Elodea canadensis, Hydrocharitaceae. J Aquat Plant Manage 1995; 33: 13-9.

5. Casper SJ, Krausch HD. Süßwasserflora von Mitteleuropa, Pteridophyta und Anthophyta, 1. Teil. Band 23. Gustav Fischer Verlag, Stuttgart; 1980, $403 \mathrm{pp}$.

6. Simpson DA. A short history on the introduction and spread of Elodea Michx. in the British Isles. Watsonia 1984; 15: 1-9.

7. Spicer KW, Catling PM. The biology of Canadian weeds, Elodea canadensis Michx. Can J Plant Sci 1988; 68: 1035-51.

8. Heikkinen RK, Leikola N, Fronzek S, Lampinen $\mathrm{R}$, Toivonen $\mathrm{H}$. Predicting distribution patterns and recent northward range shift of an Invasive aquatic plant: Elodea canadensis in Europe. BioRisk 2009; 2, 1-32. 
9. Kočić A, Horvatić J, Jelaska SD. Distribution and morphological variations of invasive macrophytes Elodea nuttallii (Planch.) H. St. John and Elodea canadensis Michx in Croatia. Acta Bot Croat 2014; 73(2): 437-46.

10. Hilt S, Gross EM, Hupfer M, Morscheid H, Mahlmann J, Melzer A et al. Restoration of submerged vegetation in shallow eutrophic lakes - A guideline and state of the art in Germany. Limnologica 2006; 36: 155-71.

11. Tokarska-Guzik B, Zaja CM, \& Zaja _CA. Geographical and ecological aspects of the spread of alien plant species in Poland. Rabitsh W, EssI F, Klingenstein F editors, Biological Invasions-from Ecology to Conservation, 7. Neobiota 2008, pp. 143-52.

12. Hussner A, van de Weyer K, Gross EM, Hilt, S. Comments on increasing number and abundance of nonindigenous aquatic macrophyte species in Germany. Weed Res 2010; 50: 519-26.

13. Kolada A, Kutyła S. Elodea canadensis (Michx.) in Polish Lakes: A non-aggressive addition to native flora. Biol Invasions 2016;18(11): 3251-64.

14. Kozhova OM, Izhboldina LA. Spread of Elodea canadensis in Lake Baikal. Hydrobiologia 1992; 239: 43-52.

15. Maiz-Tome L. Elodea canadensis. The IUCN red list of threatened species. 2016 Available from URL: http://dx.doi.org/10.2305/IUCN. UK.2016-1.RLTS.T13506646A13506651.en.

16. Josefsson M. NOBANIS-Invasive species fact sheet-Elodea canadensis, Elodea nuttallii and Elodea callitrichoides. Available from Online Database of the European Network on Invasive Alien Species; 2011.

17. Davis PH. Flora of Turkey and the East Aegean Islands. Vol. 8, First Edition, Edinburgh: Edinburgh University Press; 1984.

18. Altınyar G. Su yabancı otları. Bayındırlık ve İskan Bakanlığı, DSi Genel Müdürlüğü İşletme ve Bakım Dairesi Başkanlığı, Ankara; 1988, 239 pp.

19. Seçmen Ö, Leblebici E. Türkiye Sulak Alan Bitkileri ve Bitki Örtüsü. Ege Üniversitesi Fen Fakültesi Yayınları No:158, Bornova, İzmir;1997, 870 pp.

20. Kesici E, Gülle I, Turna İ. Eğirdir Gölü'nde Elodea canadensis Michaux'in ilk bildirimi ve istilası üzerine bir araştırma. SDÜ Fen Dergisi 2009; 4(2):120-8.

21. Huotari $\mathrm{T}$, Korpelainen $\mathrm{H}$, Leskinen $\mathrm{E}$, Kostamo K. Population genetics of the invasive water weed Elodea canadensis in Finnish waterways. Plant Syst Evol 2011; 294: 27-37.
22. Zehnsdorf A, Hussner A, Eismann F, Rönicke $H$, Melzer A. Management options of invasive Elodea nuttallii and Elodea canadensis. Limnologica 2015; 51: 110-7.

23. Aykulu G, Albay M, Akçaalan R, Tüfekçi H, Aktan Y. Species composition, abundance and seasonality of phytoplankton in a moderately deep Turkish Lake. Nova Hedwigia 2006; 130: 325-38.

24. Morkoç $E$, Tuğrul $S$, Öztürk $M$, Tüfekçi $H$, Egesel $L$, Tüfekçi $V$ et al. Trophic characteristics of the Sapanca Lake (Turkey). Croat Chem Acta 1998; 71(2): 303-22.

25. Albay M, Akçaalan R, Matthiensen A, Beattie KA. Some biochemical features of two filamentous algae isolated from Lake Sapanca, Turkey. J Fish Aqua Sci 2001; 18(1): 149-60.

26. Simpson DA. Taxonomy of Elodea Michx. in the British Isles. Watsonia 1986; 16: 1-14.

27. Golterman, HL, Clyno, RS, Ohnstad MAM. Methods for physical and chemical analysis of freshwaters. 2 nd ed. Blackwell, Oxford 1978; 315 pp.

28. APHA, AWWA, WEF. Standard methods for examination of water and wastewater. 22nd ed. Washington, American Public Health Association 2012; 1360 pp.

29. Vitousek PM, D'antonio CM, Loope LL, Rejmanek M, Westbrooks R. Introduced species: A significant component of human-caused global change. New Zeal J Ecol 1997; 21: 1-16.

30. Caffrey JM, Gallagher C, Dick JTA, Lucy F. Aquatic invasive alien species-top issues for their management. EIFAAC Occasional Paper No. 50, Rome, FAO; 2015, 63 pp.

31. Cegłowska A, Jusik S, Samecka-Cymerman A, Klink A, Szoszkiewicz K. Habitat requirements of Elodea canadensis Michx. in Polish Rivers. Oceanol Hydrobiol St 2017; 46(4): 363-78.

32. Champion PD, Clayton JS, Hofstra DE. Nipping aquatic plant invasion in the bud: weed risk assessment and the trade. Hydrobiologia 2010; 656:167-72.

33. Champion PD. Knowledge to action on aquatic invasive species: Island biosecurity - the New Zealand and South Pacific Story. Manag Biol Invasion 2018; 9(4): 383-94.

34. Coughlan NE, Cuthbert RN, Dickey JWE, Crane K, Caffrey JM, Lucy $\mathrm{FE}$, et al. Better biosecurity: spread-prevention of the invasive Asian clam, Corbicula fluminea (Müller, 1774). Manag Biol Invasion 2019; 10(1): 111-26. 